Original Article

\title{
Riverine forest as a significant habitat to harbor a wide range of bird species
}

\author{
Floresta ribeirinha como hábitat significativo para abrigo de uma gama de espécies de aves
}

\author{
M. N. Rajpara ${ }^{\circledR}$, A. H. Rajpar ${ }^{\mathrm{b}}$ () and M. Zakariac* (1) \\ aShaheed Benazir Bhutto University Sheringal Dir (Upper), Department of Forestry, Khyber Pakhtunkhwa, Pakistan \\ bJouf University, College of Engineering, Department of Mechanical Engineering, Sakaka, Saudi Arabia \\ 'Universiti Putra Malaysia, Faculty of Forestry and Environment, Department of Forest Science and Biodiversity, UPM Serdang, Selangor, \\ Malaysia
}

\begin{abstract}
Riverine forests are unique and highly significant ecosystems that are globally important for diverse and threatened avian species. Apart from being a cradle of life, it also serves as a gene pool that harbors a variety of flora and fauna species (repeated below). Despite the fact, this fragile ecosystem harbored avian assemblages; it is now disappearing daily as a result of human activity. Determining habitat productivity using bird species is critical for conservation and better management in the future. Multiple surveys were conducted over a 15-month period, from January to March 2019 , using the distance sampling point count method. A total of 250 point count stations were fixed systematically at $300 \mathrm{~m}$ intervals. In total, 9929 bird individuals were recorded, representing 57 species and 34 families. Out of 57 bird species, two were vulnerable, one was data deficient, one was nearly threatened, and the remaining 53 species were of least concern. The Eurasian Collard Dove - Streptopelia decaocto (14.641 $\pm 2.532 /$ ha), White-eared Bulbul - Pycnonotus leucotis (13.398 $\pm 4.342 / \mathrm{ha}$ ) and Common Babbler - Turdoides caudata $(10.244 \pm 2.345 /$ ha) were the three first plenteous species having higher densities. However, the densities of three species, i.e., Lesser Whitethroat - Sylvia curruca, Gray Heron - Ardea cinerea and Pallas Fish Eagle - Haliaeetus leucoryphus, were not analyzed due to the small sample size. The findings of diversity indices revealed that riverine forest has harbored the diverse avian species that are uniformly dispersed across the forest. Moreover, recording the ten foraging guilds indicated that riverine forest is rich in food resources. In addition, the floristic structure importance value index results indicated that riverine forest is diverse and rich in flora, i.e. trees, shrubs, weeds and grass, making it an attractive and productive habitat for bird species.
\end{abstract}

Keywords: Keystone, birds, riverine forest, Kot Dinghano, habitat, diversity.

\begin{abstract}
Resumo
As florestas ribeirinhas são ecossistemas únicos e altamente significativos que são globalmente importantes para diversas espécies de aves ameaçadas de extinção. Além de serem o berço da vida, também servem como um conjunto genético que abriga uma variedade de espécies da flora e da fauna. Apesar disso, esse frágil ecossistema abrigava um conjunto de aves, mas agora está desaparecendo diariamente como resultado da atividade humana. Determinar a produtividade do hábitat usando espécies de pássaros é fundamental para a conservação e melhor gestão no futuro. Vários levantamentos foram realizados ao longo de um período de 15 meses, de janeiro de 2018 a março de 2019, por meio do método de contagem de pontos de amostragem de distância. Foram fixadas sistematicamente 250 estações de contagem de pontos em intervalos de $300 \mathrm{~m}$. No total, foram registrados 9.929 indivíduos de aves, representando 57 espécies e 34 famílias. Das 57 espécies de aves, duas eram vulneráveis, uma tinha dados insuficientes, uma estava quase ameaçada e as 53 espécies restantes eram as menos preocupantes. O: Pomba de colar euroasiática - Streptopelia decaocto (14.641 $\pm 2.532 / \mathrm{ha})$, o Bulbul de orelha branca - Pycnonotus leucotis ( $13.398 \pm 4.342 / \mathrm{ha}$ ) e Tagarela comum - Turdoides caudata (10.244 $\pm 2.345 / \mathrm{ha}$ ) foram as três primeiras espécies abundantes com maiores densidades. No entanto, as densidades de três espécies, Papa-amoras-cinzento (Sylvia curruca), Garça-real-europeia (Ardea cinerea) e Águia-pescadora de Pallas (Haliaeetus leucoryphus), não foram analisadas por causa do pequeno tamanho da amostra. Os resultados dos índices de diversidade revelaram que a floresta ribeirinha abrigou diversas espécies de aves que estão uniformemente dispersas pela floresta. Além disso, o registro das dez guildas de forrageamento indicou que a floresta ribeirinha é rica em recursos alimentares. Além disso, os resultados do índice de valor de importância da estrutura florística indicaram que a floresta ribeirinha é variada e rica em flora, ou seja, árvores, arbustos, ervas daninhas e grama, tornando-a um hábitat atraente e produtivo para espécies de aves.
\end{abstract}

Palavras-chave: Keystone, pássaros, floresta ribeirinha, Kot Dinghano, hábitat, diversidade.

*e-mail: mzakaria@upm.edu.my

Received: September 8, 2021 - Accepted: December 3, 2021

This is an Open Access article distributed under the terms of the Creative Commons Attribution License, which permits unrestricted use, distribution, and reproduction in any medium, provided the original work is properly cited. 


\section{Introduction}

Conservation status and population structure reflect habitat productivity and the effects of human footprints on bird populations and habitat (Thompson III et al., 2002; DeSante et al., 2005; Kaminski et al., 2006; Gregory et al., 2006). This might be because bird species play a noteworthy role in seed dispersal and pest control (Dale et al., 2002; Ellison et al., 2005; Morrison, 2009; Caro, 2010). The population attributes of birds reflects long-term temporal changes in floral cover, forest management operations, and threats posed by anthropogenic activities, as certain species become threatened, endangered, or vulnerable as a result of these activities (Burger, 2006).

Riverine forest is an area where the land and river interface. These forest areas are hotspots of aquatic and terrestrial biodiversity, with a wide range of floral structures (trees, shrubs, and grasses) and fauna (mammals, birds, amphibians, and reptiles) (Ward et al., 2002; Amitha Bachan, 2003; Capon et al., 2016). They are dominated by hydrophilic plants, which can thrive in both wet and dry environments. These forests provide a safe haven for a diverse range of bird species.

Furthermore, riverine forests is prolific ecosystem, it serves as a gene pool flora, raw material for medications, critical habitat for wide range of bird species and ample food resources. Due to the strong reliance of local residents on agriculture, riverine forests are at the forefront of conservation and protection. They are also hotspots for agricultural production. Despite the fact that these forests are crucial, they are under severe threat from overexploitation, uncontrolled grazing, fuel wood collection, agricultural development, and border conflicts (Stave et al., 2007; Merawi, 2016).

The productivity of riverine forests using bird assemblages has received little attention, and its significance is frequently underestimated. Human interventions in Pakistan have resulted in the loss and degradation of vast riverine forest areas, resulting in a fall in bird populations. The number of many bird species has plummeted at an alarming rate as a result of habitat loss and degradation caused by human footprints in land use patterns, unregulated use of pesticides, illegal hunting and trapping. For example, due to human involvement, Sociable Lapwing - Vanellus gregarious, Jerdon's Babbler - Moupinia altirostris, Marbled Duck - Marmaronetta angustriostris, Sarus Crane - Grus antigone, Ferruginous Duck - Aythya nyroca, Lesser White-fronted Goose - Anser erythropus and White-headed Duck - Oxyura leucocephala (Sekercioğlu et al., 2004; Khalique et al., 2012; Khan and Ali, 2015; Umar et al., 2018) have become vulnerable and endangered.

Unfortunately, no research has been done utilizing bird assemblages to analyze the productivity of riverine forests across the country. As a result, this study was carried out to determine productivity through bird assemblages to improve future management plans and conservation (Hill et al., 2001; Cahill et al., 2006).

\section{Materials and Methods}

\subsection{Study area}

This research took place in the Kot Dinghano Riverine Forest, which is located along the right bank of the Indus River Lakhat between $101^{\circ} 10^{\prime}$ and $101^{\circ} 50$ ' longitude and $2^{\circ} 50^{\prime}$ and $3^{\circ} 00^{\prime}$ latitude (Figure 1 ) in the district of Shaheed Banazirabad in Sindh, Pakistan. This riverine forest is approximately 4000 acres in size and has unique characteristics, such as a heterogeneous landscape made up of forests, marshes, and agricultural areas, which represent

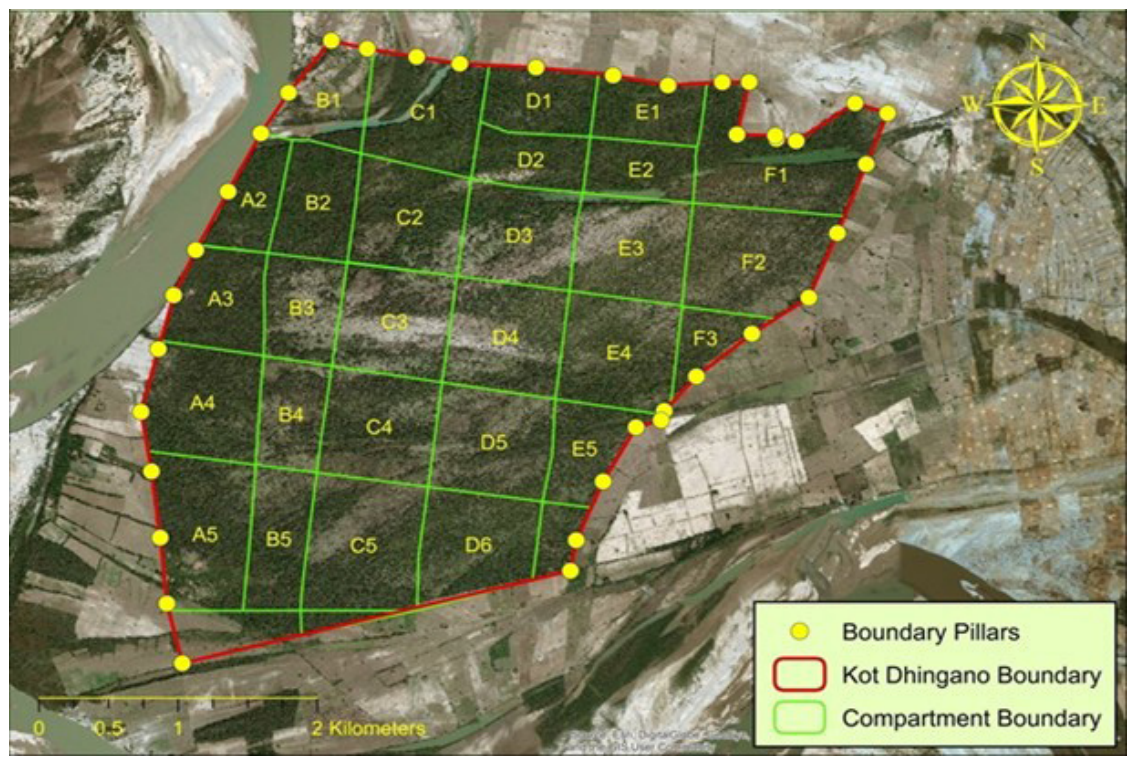

Figure 1. Location map of the study area. A-F = The names of compartments. 
special environmental conditions for attracting game and nongame birds. The riverine forest is rich in floral structure (Figure 2), food supplies, and nesting grounds, all of which have the potential to attract bird species.

\subsection{Survey of bird species}

Bird surveys were performed employing the distance sampling point count method for 15 consecutive months from January 2018 to March 2019. The distance sampling point count method is one of the most quantitative and robust techniques to examine population structure and habitat characteristics (Verner and Purcell, 1999; Codesido and Bilenca, 2000) across different habitats. This method involves the visual and auditory detection of birds with fixed or variable radius plots and provides important information on the bird population structure and habitat characteristics (Verner and Ritter, 1985; Mills et al., 2000). Bird detection in the riverine forest environment, on the other hand, may vary based on floral foliage density, canopy cover, visibility, sound perception, and observer competence (Schieck, 1997; Whitman et al., 1997; Blake and Loiselle, 2000).

To avoid double counting the same bird individuals at more than one station, a total of 250 point count stations were randomly placed at $300 \mathrm{~m}$ intervals. The birds were surveyed at each point count station for 15 minutes (Freeman et al., 2003; Lee and Marsden, 2008). The distance from the bird to the observer was recorded using visual estimation within $100 \mathrm{~m}$ long distance bands. The surveys were conducted between 7:00 a.m. and 11:00 a.m. This is the best time to go because the majority of the birds were active in performing multiple activities. Flying birds, on the other hand, were not documented since their originating locations were unknown. The sampling methodology was followed as prescribed by Buckland (2006), Sutherland (2006), Nadeau et al. (2008) and Thomas et al. (2010).

\subsection{Floral survey}

One of the most significant factors is determining the structure and content of floral species composition and cover. This might be because it shows how much area is covered by vegetation (such as trees, shrubs, weeds, and grasses), as well as the habitat structure, appropriateness, and productivity for bird species to thrive. The quadrat technique was used to determine the floral structure. In this study, quadrates of various sizes were used, e.g., $20 \times 20 \mathrm{~m}$ for trees, $5 \times 5 \mathrm{~m}$ for shrubs and $1 \times 1 \mathrm{~m}$ for grasses and weeds, to examine the floral species composition and cover percentage. The methodology was followed as stated by Keighery (1994), Barker (2001), Clarke (2009) and Schulz et al. (2009).

\section{Data Analysis}

\subsection{IUCN conservation status}

The IUCN Red List was used to determine the conservation status of detected bird species (IUCN, 2018).

\subsection{Relative abundance}

Relative abundance is the number of bird individuals of a particular species that occupied the riverine forest habitat (Bibby et al., 2000). The relative abundance of birds varies with altitude, aspect, microclimate conditions, geographic distribution, and restoration efforts (McGill et al., 2007; Verberk, 2011). The relative abundance of riverine forest bird species was determined using Equation 1:

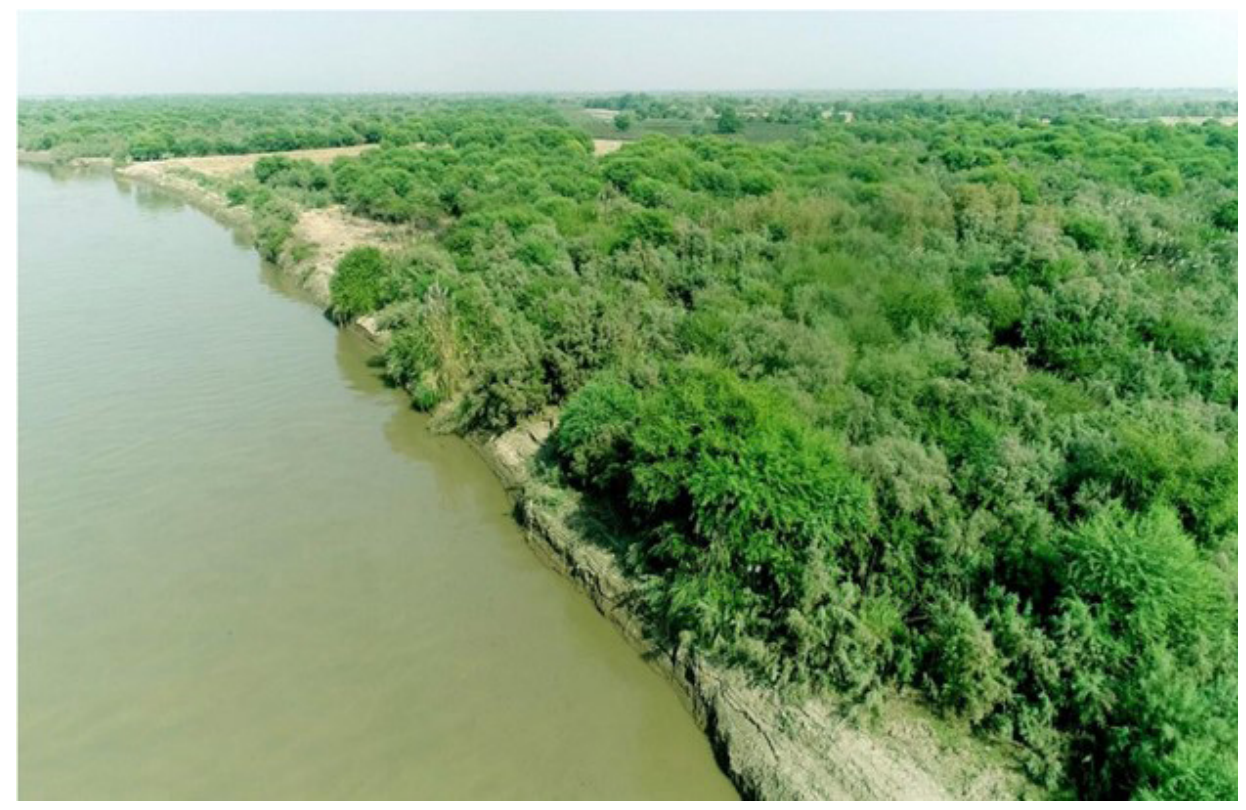

Figure 2. Aesthetic view of the riverine forest habitat. 
Relative Species Abundance $(\%)=I \mathrm{si} / \sum N$ si X 100

where, ISi = total number of bird individuals of overall detected bird species, $/ \sum \mathrm{Nsi}$ = observed total number of bird species (Anderson et al., 2015).

\subsection{Bird density}

The number of birds per hectare is known as bird density. Determining the current population of bird species that occupy riverine forests is critical for future management and conservation efforts. The bird population was determined through DISTANCE Software (Version 7.1) by Buckland et al. (2004).

The "detection function" $g(y)$, i.e., the probability of the birds at distance $y$, is determined by sampling the distribution of recorded distances between observer and object. This aids in determining the mean probability of spotting a bird within $\mathrm{w}$ of the point, marked $\mathrm{Pa}$, at a particular position. The bird density can be determined using Equation 2:

$$
\hat{D}=\frac{1}{a} \sum_{i=1}^{n} \frac{1}{\hat{P}_{a}\left(\mathbf{z}_{i}\right)}
$$

where, $a$ is the size of the covered region, $n$ is the number of birds seen, and $P^{\wedge} a(\mathbf{z} i)$ is the estimated probability of detecting the $i$ th bird given that it is within $w$ of the point and has the covariate values zi (Marsden, 1999; Buckland, 2006).

\subsection{Diversity indices}

The diversity indices, i.e., Species diversity (variability), species richness and species evenness (distribution) reflect the productivity and biodiversity of a particular area. Ascertaining the diversity indices in riverine forests indicates that either biodiversity resources are expanding or diminishing or it will be useful in developing wildlife management and conservation plans in the future, particularly for bird species. Community Analysis Package Software (CAP: version 4.0) by Henderson and Seaby (2007) was used to determine diversity indices such as Shannon's Diversity Index, Margalef's Richness Index, and Pielou J Evenness Index to estimate the appropriateness of riverine habitat for a wide range of bird species.

\subsubsection{Shannon's diversity index}

It is an index that takes into account the number of different bird species that occur in riverine forests, as well as their relative abundance. It provides data on the rarity and abundance of birds in riverine forests. Shannon's diversity index formula was used to calculate the bird species diversity of riverine forests, as shown below (equation 3 ):

$$
\mathrm{H}^{\prime}=\sum[(p i) \times \operatorname{In}(p i)]
$$

where, $\mathrm{H}^{\prime}$ designates diversity, $\mathrm{S}$ indicates the number of bird species, $i$ specifies the abundance of bird species, $N$ is the total number of all bird individuals, $p_{i}$ is the bird relative abundance of each species, and $\ln$ is the natural logarithm.

\subsubsection{Simpson's diversity index}

It is an index that takes into account the number of bird species found in riverine forests, as well as their relative abundance. It gives more weight to dominating bird species than unusual bird species. It is frequently used to measure habitat productivity. Simpson's diversity index formula was used to estimate the bird species diversity of riverine forests (Equation 4):

$$
\mathrm{D}=1-\Sigma \mathrm{n}(\mathrm{n}-1) / \mathrm{N}(\mathrm{N}-1)
$$

Where, $p i=$ the proportion $(\mathrm{n} / \mathrm{N})$ of individuals of one particular bird species ( $\mathrm{n}), \mathrm{N}=$ the total number of bird individuals, $\Sigma=$ the sum of the calculations of bird species (Glen, 2021).

\subsubsection{Margalef's richness index}

Species richness is a measure of the number of bird species detected in riverine forests. Margalef's richness index formula was used to assess the bird species richness of riverine forests (Equation 5):

$$
\mathrm{R}=(\mathrm{S}-1) / \ln \mathrm{N}
$$

where, $\mathrm{S}$ is the total number of species and $\mathrm{N}$ is the total number of individuals in the sample.

\subsubsection{Pielou J evenness index}

The distribution of bird abundance over the riverine forest is described as species evenness. It depicts the distribution of bird species in riverine forests. The Pielou $\mathrm{J}$ evenness index formula was used to determine the evenness of bird species in riverine forests (Equation 6):

$$
\mathrm{J}=\mathrm{H} / \log (\mathrm{S})
$$

where, $\mathrm{H}=$ is the observed Shannon-Wiener index and $\mathrm{S}=$ is the total number of bird species in the coniferous forest.

\subsection{Foraging guild structure}

A foraging guild structure is a group of bird species that use comparable food resources and capture them in the same or different ways. The bird species were grouped into ten groups. The methodology was followed as described by Graaf et al. (1985), Ehrlich et al. (1988), and Thorngate et al. (2006).

\subsection{Vegetation importance value index}

The significance of trees, shrubs, weeds, and grasses in riverine forest habitats is indicated by the importance value index. It takes into account the relative value of each 
species' density, frequency, and relative cover, all of which show the ecological relevance of the riverine forest's floral structure. The importance value index identifies the most dominant and rarest flora in riverine habitats, as well as their potential productivity. The following formula was used to calculate the value of vegetation structure (IVI) of riverine forest habitat (Equation 7):

$$
\mathrm{IVI}=\mathrm{RF}+\mathrm{RD}+\mathrm{RC}
$$

where, $\mathrm{RF}$ = relative frequency, $\mathrm{RD}=$ relative density and $\mathrm{RC}=/ \mathrm{r} /$ relative cover.

\subsection{Relative density ( $R D)$}

The number of individuals of a given plant species per unit area is known as density (ha or ${ }^{\mathrm{km} 2}$ ). Relative density (RD) is the proportion of each plant species' contribution to the total number of plants in an area. The relative density of riverine forest flora was calculated using the formula below (Equation 8):

$$
\mathrm{RD}=\begin{aligned}
& \text { No. of individuals of each plant species total number } \\
& \text { of plant individuals of all detected plant species }
\end{aligned}
$$

\subsection{Relative frequency $(R F)$}

A plant species' frequency can be defined as a proportion of the quadrate in which it occurs. The relative frequency (RF) is a frequency that is expressed as a percentage of the overall frequency. The following formula was used to compute the relative frequency of riverine forest flora species (Equation 9):

$$
R F=\begin{aligned}
& \text { No of quadrate in which plant species } \\
& \text { occurTotal No. of quadrate taken }
\end{aligned}
$$

\section{Results}

\subsection{Bird species composition and relative abundance}

In total, 9929 bird individuals were recorded using the distance sampling point count approach, belonging to 57 species and 34 families. Based on the IUCN Red List, two species were vulnerable (VU), one was data deficient (DD), one was nearly threatened (NT), and the remaining 53 species were of least concern (LC). The Eurasian Collard Dove - Streptopelia decaocto (15.56\%), Whiteeared Bulbul - Pycnonotus leucotis (11.94\%), and Gray Francolin - Francolinus pondicerianus $(10.17 \%)$ were the three foremost dominant bird species having the highest relative abundance in the Kot Dinghano Riverine forest. In contrast, Lesser Whitethroat - Sylvia curruca (0.07\%), Gray Heron - Ardea cinerea (0.06\%), and Pallas Fish Eagle - Haliaeetus leucoryphus (0.05\%) were the rarest riverine forest bird species (Table 1 ).

\subsection{Distribution of bird abundance in riverine forest habitat}

\subsubsection{Log series model}

It is the most widely used mathematically intermediate model between the broken stick and log series. The lognormal model test revealed that bird species in the riverine forest are widely dispersed. However, sampling error may have an impact on bird species distribution in the study area (Figure 3).

\subsubsection{Truncated lognormal model}

This model is comprised of two parameters: (i) location and (ii) dispersion. The truncated lognormal model indicated that the distribution of bird species, both sparsely and thickly, is influenced by habitat productivity and human interference. Furthermore, the size and quantity of samples have an impact on the dispersal of the avian community (Figure 4).

\subsubsection{Broken stick model}

This model is widely used to find bird populations that are more or less evenly dispersed in the same habitat. The graph demonstrated that each bird species is equally plentiful or widely spread in the riverine forest (Figure 5).

\subsection{Bird density}

The results of distance software analysis (DSA) demonstrated that four bird species, namely,

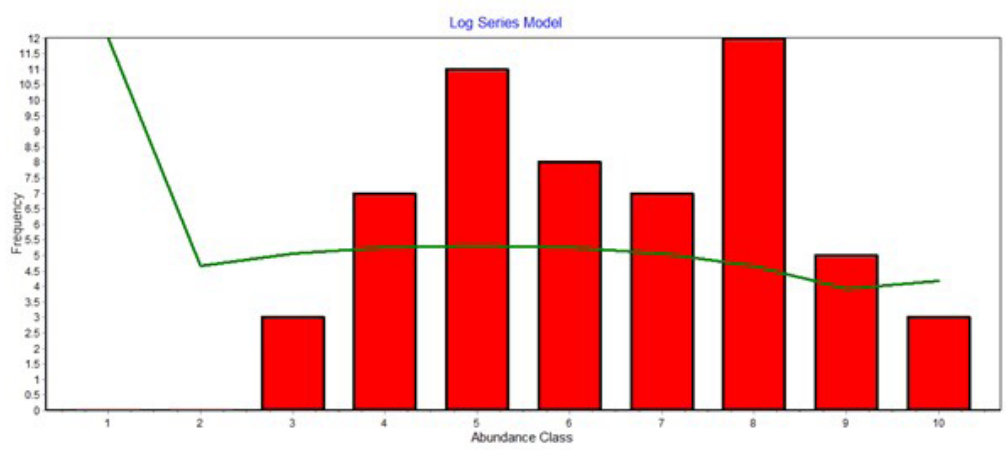

Figure 3. Log series model indicating the bird abundance of riverine forest habitat. 
Table 1. Relative abundance of avian species detected in Kot Dinghano Riverine forest, Lakhat.

\begin{tabular}{|c|c|c|c|c|c|}
\hline S. No & Scientific Name & Common Name & No of Detections & $\%$ & IUCN Status \\
\hline Columbidae & Streptopelia decaocto & Eurasian Collard Dove & 1545 & 15.56 & LC \\
\hline Pycnonotidae & Pycnonotus leucotis & White-eared Bulbul & 1186 & 11.94 & LC \\
\hline Phasianidae & Francolinus pondicerianus & Gray Francolin & 1010 & 10.17 & LC \\
\hline Leiothrichidae & Turdoides striata & Jungle Babbler & 648 & 6.53 & LC \\
\hline Phylloscopidae & Phylloscopus neglectus & Plain Leaf Warbler & 432 & 4.35 & LC \\
\hline Hirundinidae & Riparia paludicola & Brown-throated Sand Martin & 384 & 3.86 & LC \\
\hline Scolopacidae & Tringa totanus & Common Redshank & 340 & 3.42 & LC \\
\hline Pellorneidae & Chaetornis striata & Bristled Grassbird & 326 & 3.28 & VU \\
\hline Leiothrichidae & Turdoides caudata & Common Babbler & 322 & 3.24 & LC \\
\hline Ardeidae & Ardeola grayii & Indian Pond Heron & 219 & 2.21 & LC \\
\hline Rhipiduridae & Rhipidura aureola & White-browed Fantail & 217 & 2.19 & LC \\
\hline Charadriidae & Vanellus indicus & Red-wattled Lapwing & 216 & 2.18 & LC \\
\hline Muscicapidae & Phoenicurus ochruros & Black Redstart & 215 & 2.17 & LC \\
\hline Muscicapidae & Saxicoloides fulicatus & Indian Robin & 214 & 2.16 & LC \\
\hline Corvidae & Dendrocitta vagabunda & Rufous Treepie & 194 & 1.95 & LC \\
\hline Ardeidae & Egretta garzetta & Little Egret & 183 & 1.84 & LC \\
\hline Recurvirostridae & Himantopus himantopus & Black-winged Stilt & 180 & 1.18 & LC \\
\hline Muscicapidae & Saxicola caprata & Pied Bush Chat & 175 & 1.76 & LC \\
\hline Anatidae & Anas strepera & Gadwall & 167 & 1.68 & LC \\
\hline Laridae & Sterna aurantia & River Tern & 143 & 1.44 & LC \\
\hline Alcidinidae & Ceryle rudis & Pied Kingfisher & 132 & 1.33 & LC \\
\hline Corvidae & Corvus splendens & House Crow & 126 & 1.27 & LC \\
\hline Motacillidae & Motacilla alba & White Wagtail & 125 & 1.26 & LC \\
\hline Pycnonotidae & Pycnonotus cafer & Red-vented Bulbul & 121 & 1.22 & LC \\
\hline Muscicapidae & Muscicapa sibirica & Dark-sided Flycatcher & 117 & 1.18 & LC \\
\hline Scolopacidae & Tringa. Hypoleucos & Common Sandpiper & 102 & 1.03 & LC \\
\hline Ardeidae & Egretta albus & Great Egret & 89 & 0.90 & LC \\
\hline Alcidinidae & Halcyon smyrnensis & White-throated Kingfisher & 72 & 0.73 & LC \\
\hline Scolopacidae & Tringa stagnatilis & Marsh Sandpiper & 58 & 0.59 & LC \\
\hline Passeridae & Passer domesticus & House Sparrow & 55 & 0.55 & LC \\
\hline Alcidinidae & Alcedo atthis & Common Kingfisher & 45 & 0.45 & LC \\
\hline Phylloscopidae & Phyllosocopus inornatus & Yellow-browed Warbler & 45 & 0.45 & LC \\
\hline Phalacrocoracidae & Microcarbo niger & Little Cormorant & 44 & 0.44 & LC \\
\hline Phalacrocoracidae & Phalacrocorax carbo & Great Cormorant & 35 & 0.35 & DD \\
\hline Meropidae & Merops orientalis & Green Bee-eater & 34 & 0.34 & LC \\
\hline Picidae & Dinopium javanense & Common Flameback & 34 & 0.34 & LC \\
\hline Dicruridae & Dicrurus macrocercus & Black Drongo & 32 & 0.32 & LC \\
\hline Ardeidae & Butriodes striata & Little Heron & 29 & 0.29 & LC \\
\hline Accipitridae & Aquila rapax & Tawny Eagle & 28 & 0.28 & LC \\
\hline Laridae & Sterna acuticauda & Black-bellied Tern & 26 & 0.26 & NT \\
\hline Columbidae & Spiopelia senegalensis & Laughing Dove & 26 & 0.26 & LC \\
\hline Rallidae & Gallinula chloropus & Common Moorhen & 25 & 0.25 & LC \\
\hline Coraciidae & Coracias benghalensis & Indian Roller & 23 & 0.23 & LC \\
\hline Podicipedidae & Tachybaptus ruficollis & Little Grebe & 23 & 0.23 & LC \\
\hline Nectarniidae & Cinnyris asiaticus & Purple Sunbird & 21 & 0.21 & LC \\
\hline Accipitridae & Accipiter nisus & Eurasian Sparrow Hawk & 17 & 0.17 & LC \\
\hline Alaudidae & Ammomanes phoenicura & Rufous-tailed Lark & 17 & 0.17 & LC \\
\hline Alaudidae & Galerida cristata & Crested Lark & 16 & 0.16 & LC \\
\hline Accipitridae & Accipiter virgatus & Besra & 15 & 0.15 & LC \\
\hline Cuculidae & Centropus sinensis & Greater Coucal & 14 & 0.14 & LC \\
\hline Upupidae & Upupa epops & Common Hoopoe & 13 & 0.13 & LC \\
\hline Scolopacidae & Tringa glareola & Wood Sandpiper & 12 & 0.12 & LC \\
\hline Campephagidae & Pericrocotus cinnamomeus & Small Minivet & 12 & 0.12 & LC \\
\hline Cisticolidae & Prinia inornata & Plain Prinia & 12 & 0.12 & LC \\
\hline Sylviidae & Sylvia curruca & Lesser Whitethroat & 7 & 0.07 & LC \\
\hline Ardeidae & Ardea cinerea & Gray Heron & 6 & 0.06 & LC \\
\hline \multirow[t]{2}{*}{ Accipitridae } & Haliaeetus leucoryphus & Pallas Fish Eagle & 5 & 0.05 & VU \\
\hline & & Total & 9929 & & \\
\hline
\end{tabular}

LC = Least Concern; VU = Vulnerable; DD = Data Deficient; NT = Nearly Threatened. 


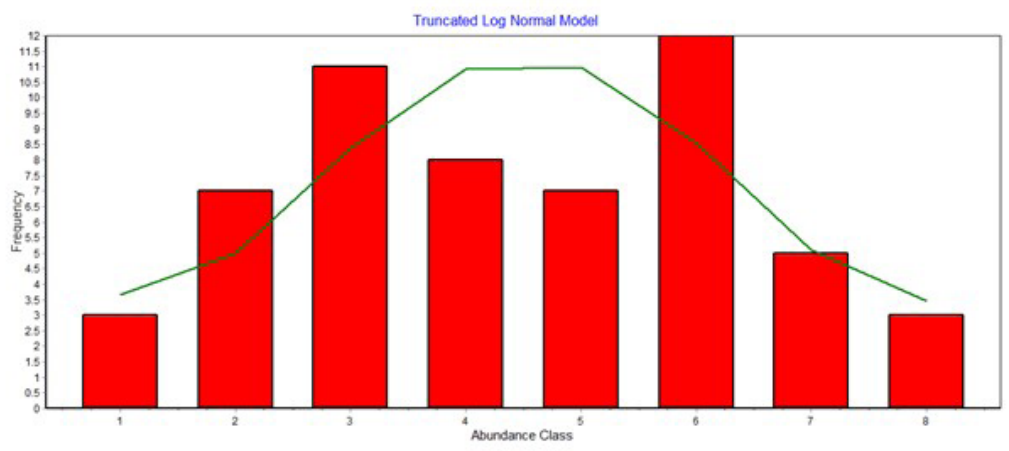

Figure 4. Truncated log normal model indicates the bird abundance of riverine forest habitat.

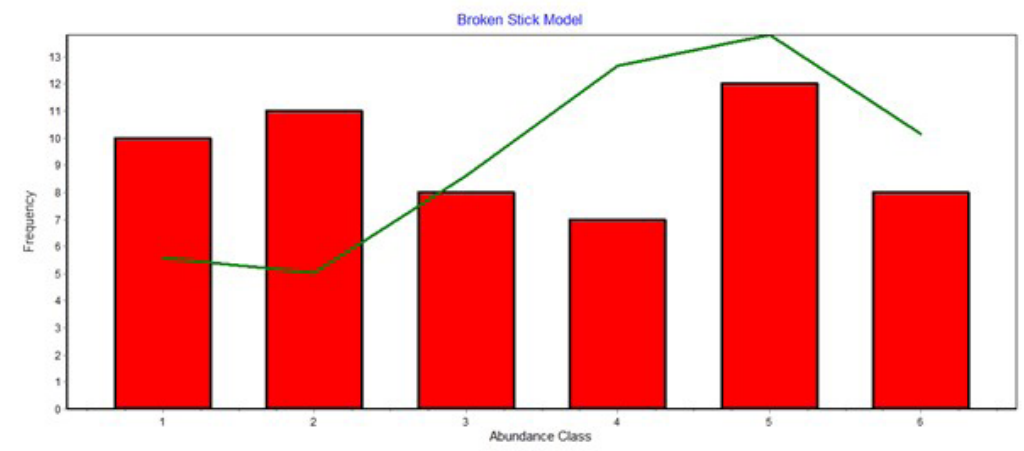

Figure 5. Broken stick model indicating the bird abundance of riverine forest habitat.

Eurasian Collard Dove - Streptopelia decaocto (14.641 $\pm 2.532 /$ ha $)$, White-eared Bulbul - Pycnonotus leucotis (13.398 $\pm 4.342 /$ ha), Common Babbler Turdoides caudate (10.244 $\pm 2.345 / \mathrm{ha})$, and Gray Francolin - Francolinus pondicerianus $(9.453 \pm 4.321 /$ ha $)$ had highest bird density/ha. In contrast, the lowest bird density/ha was recorded for House Sparrow - Passer domesticus ( $0.231 \pm 0.127 /$ ha $)$, followed by Small Minivet - Pericrocotus cinnamomeus ( $0.213 \pm 0.121 / \mathrm{ha})$ and Eurasian Sparrow Hawk - Accipiter nisus (0.172 $\pm 0.122 /$ ha). Furthermore, the density of 3 species, i.e., Lesser Whitethroat Sylvia curruca, Gray Heron - Ardea cinerea and Pallas Fish Eagle - Haliaeetus leucoryphus, was not analyzed due to the small sample size, i.e., fewer than ten individuals were detected (Table 2)

\subsection{Diversity indices of bird species}

In this study, diversity refers to the number of various bird species found in a Kot Dinghano Riverine forest habitat. The findings of the Community Analysis Package showed that bird species are varied (Simpson's $\mathrm{D}=15.26$ and Shannon's H' = 3.212), rich (Margalef's $\mathrm{R}_{1}=5.977$ ) and evenness (Pielou JE $=0.798$ ), indicating that the Kot Dinghano Riverine forest is a productive habitat. The habitat's productivity, i.e., floral characteristics and food resources attracted a diverse range of bird species to utilize riverine forest habitats (Table 3 ).

\subsection{Foraging guilds of bird species}

Notably, observed birds were divided into ten foraging guilds based on food preferences, territorial preferences, and food capture tactics. Insectivores (27.60\%) were the foremost abundant guild that significantly exploited the riverine forest habitat, followed by Carnivores/Piscivores/Insectivores (18.95\%) and Grainivores (15.82\%). In contrast, Carnivores (0.65\%), Nectarivores/Insectivores (0.21\%), and Carnivores/ Insectivores $(0.14 \%)$ were the rarest foraging guilds in the study area. The recording of higher foraging guilds demonstrated that the food supplies in riverine forests are abundant and diversified, making it a productive habitat (Table 4).

\subsection{Floristic structure and importance value index}

Strikingly, the floristic structure of the Kot Dinghano Riverine forest revealed that it is diversified and abundant in floral species composition. The IVI method was used to assess the ecological significance of floral structure and species composition in the Kot Dinghano Riverine forest. The results showed that riverine forest consists of trees, shrubs, weeds, and grasses. The highest important value (23.91\%) was obtained for the Gum Arabic Tree, indicating that this tree species densely occupied the riverine forest, while the lowest (2.38\%) was determined for Jand, indicating that this species was rare and occupied only a small proportion of the study area. Similarly, IVI 
Table 2. List of bird density (birds/ha) in Kot Dinghano Riverine forest.

\begin{tabular}{|c|c|c|c|c|}
\hline Family & Scientific Name & Common Name & Density (birds/ha & $\begin{array}{c}\text { Detection } \\
\text { Probability (\%) }\end{array}$ \\
\hline Columbidae & Streptopelia decaocto & Eurasian Collard Dove & $14.641 \pm 2.532$ & $98.60 \%$ \\
\hline Pycnonotidae & Pycnonotus leucotis & White-eared Bulbul & $13.398 \pm 4.342$ & $95.00 \%$ \\
\hline Leiothrichidae & Turdoides caudata & Common Babbler & $10.244 \pm 2.345$ & $89.30 \%$ \\
\hline Phasianidae & Francolinus pondicerianus & Gray Francolin & $9.453 \pm 4.321$ & $99.40 \%$ \\
\hline Phylloscopidae & Phylloscopus neglectus & Plain Leaf Warbler & $6.947 \pm 2.092$ & $99.90 \%$ \\
\hline Hirundininae & Riparia paludicola & Brown-throated Sand Martin & $6.238 \pm 4.464$ & $93.70 \%$ \\
\hline Leiothrichidae & Turdoides striata & Jungle Babbler & $4.755 \pm 1.980$ & $83.90 \%$ \\
\hline Muscicapidae & Saxicola caprata & Pied Bush Chat & $4.213 \pm 0.893$ & $99.20 \%$ \\
\hline Meropidae & Merops orientalis & Green Bee-eater & $3.763 \pm 1.232$ & $100.00 \%$ \\
\hline Pycnnotidae & Pycnonotus cafer & Red-vented Bulbul & $3.598 \pm 1.672$ & $100.00 \%$ \\
\hline Rhipiduridae & Rhipidura aureola & White-browed Fantail & $3.463 \pm 0.436$ & $98.30 \%$ \\
\hline Corvidae & Dendrocitta vagabunda & Rufous Treepie & $2.763 \pm 0.564$ & $98.90 \%$ \\
\hline Muscicapidae & Phoenicurus ochruros & Black Redstart & $2.566 \pm 0.456$ & $99.70 \%$ \\
\hline Muscicapidae & Saxicoloides fulicatus & Indian Robin & $2.129 \pm 0.980$ & $100.00 \%$ \\
\hline Anatidae & Anas strepera & Gadwall & $2.129 \pm 0.881$ & $77.60 \%$ \\
\hline Scolopacidae & Tringa totanus & Common Redshank & $1.983 \pm 0.789$ & $98.70 \%$ \\
\hline Pellorneidae & Chaetornis striata & Bristled Grassbird (VU) & $1.899 \pm 0.657$ & $99.70 \%$ \\
\hline Dicruridae & Dicrurus macrocercus & Black Drongo & $1.873 \pm 0.983$ & $98.00 \%$ \\
\hline Corvidae & Corvus splendens & House Crow & $1.645 \pm 0.78 \mathrm{I}$ & $93.20 \%$ \\
\hline Phalacrocoracidae & Microcarbo niger & Little Cormorant & $1.214 \pm 0.678$ & $97.20 \%$ \\
\hline Picidae & Dinopium javanense & Common Flameback & $1.213 \pm 0.311$ & $99.40 \%$ \\
\hline Phylloscopidae & Phyllosocopus inornatus & Yellow-browed Warbler & $1.021 \pm 0.348$ & $98.20 \%$ \\
\hline Ardeidae & Egretta garzetta & Little Egret & $0.978 \pm 0.423$ & $98.90 \%$ \\
\hline Phalacrocoracidae & Phalacrocorax carbo & Great Cormorant (DD) & $0.954 \pm 0.342$ & $99.20 \%$ \\
\hline Motacillidae & Motacilla alba & White Wagtail & $0.879 \pm 0.323$ & $99.90 \%$ \\
\hline Muscicapidae & Muscicapa sibrica & Dark-sided Flycatcher & $0.870 \pm 0.343$ & $99.20 \%$ \\
\hline Rallidae & Gallinula chloropus & Common Moorhen & $0.732 \pm 0.542$ & $98.00 \%$ \\
\hline Scolopacidae & Tringa stagnatilis & Marsh Sandpiper & $0.732 \pm 0.230$ & $97.50 \%$ \\
\hline Coraciidae & Coracias bengalensis & Indian Roller & $0.682 \pm 0.348 /$ & $98.50 \%$ \\
\hline Ardeidae & Butriodes striata & Little Heron & $0.678 \pm 0.890$ & $97.9 \%$ \\
\hline Podicipedidae & Tachybaptus ruficollis & Little Grebe & $0.678 \pm 0.438$ & $96.00 \%$ \\
\hline Alaudidae & Ammomanes phoenicura & Rufous-tailed Lark & $0.653 \pm 0.398$ & $97.4 \%$ \\
\hline Recurvirostridae & Himantopus himantopus & Black-winged Stilt & $0.650 \pm 0.289$ & $96.7 \%$ \\
\hline Charadriidae & Vanellus indicus & Red-wattled Lapwing & $0.649 \pm 0.231$ & $94.90 \%$ \\
\hline Alcidinidae & Halcyon smyrnensis & White-throated Kingfisher & $0.637 \pm 0.213$ & $99.40 \%$ \\
\hline Upupidae & Upupa epops & Common Hoopoe & $0.623 \pm 0.489$ & $98.90 \%$ \\
\hline Ardeidae & Ardeola grayii & Indian Pond Heron & $0.623 \pm 0.320$ & $94.60 \%$ \\
\hline Laridae & Sterna aurantia & River Tern & $0.623 \pm 0.308$ & $99.00 \%$ \\
\hline Alcidinidae & Alcedo atthis & Common Kingfisher & $0.565 \pm 0.416$ & $98.50 \%$ \\
\hline Nectariniidae & Cinnyris asiaticus & Purple Sunbird & $0.562 \pm 0.342$ & $98.00 \%$ \\
\hline Scolopacidae & Tringa glareola & Wood Sandpiper & $0.548 \pm 0.348$ & $98.90 \%$ \\
\hline Alcidinidae & Ceryle rudis & Pied Kingfisher & $0.538 \pm 0.243$ & $99.90 \%$ \\
\hline Cuculidae & Centropus sinensis & Greater Coucal & $0.532 \pm 0.342$ & $98.90 \%$ \\
\hline Accipitridae & Aquila rapax & Tawny Eagle & $0.452 \pm 0.148$ & $99.40 \%$ \\
\hline Laridae & Sterna acuticauda & Black-bellied Tern (NT) & $0.434 \pm 0.252 /$ & $95.00 \%$ \\
\hline Columbidae & Spiopelia senegalensis & Laughing Dove & $0.421 \pm 0.209$ & $97.50 \%$ \\
\hline Scolopacidae & Tringa. hypoleucos & Common Sandpiper & $0.342 \pm 0.241$ & $98.20 \%$ \\
\hline Cisticolidae & Prinia inornata & Plain Prinia & $0.328 \pm 0.234$ & $97.90 \%$ \\
\hline Alaudidae & Galerida cristata & Crested Lark & $0.324 \pm 0.287$ & $98.90 \%$ \\
\hline Ardeidae & Egretta albus & Great Egret & $0.312 \pm 0.143$ & $99.90 \%$ \\
\hline Accipitridae & Accipiter virgatus & Besra & $0.268 \pm 0.126 /$ & $95.00 \%$ \\
\hline Passeridae & Passer domesticus & House Sparrow & $0.231 \pm 0.127$ & $99.00 \%$ \\
\hline Campephagidae & Pericrocotus cinnamomeus & Small Minivet & $0.213 \pm 0.121$ & $98.0 \%$ \\
\hline Accipitridae & Accipiter nisus & Eurasian Sparrow Hawk & $0.172 \pm 0.122$ & $93.00 \%$ \\
\hline Sylviidae & Sylvia curruca & Lesser Whitethroat & NA & - \\
\hline Ardeidae & Ardea cinerea & Gray Heron & NA & - \\
\hline Accipitridae & Haliaeetus leucoryphus & Pallas Fish Eagle (VU) & NA & - \\
\hline
\end{tabular}

$\mathrm{NA}=$ Not Analyzed due to low number of detections. 
Table 3. Diversity indices of bird species in Kot Dinghano Riverine forest.

\begin{tabular}{ll}
\hline \multicolumn{1}{c}{ Indices } & Index Values \\
\hline Diversity Index & \\
\hline Shannon's Diversity index & $\mathrm{H}^{\prime}=3.212$ \\
Simpson's Diversity Index & $\mathrm{D}=15.26$ \\
\hline Richness Index & \\
\hline Margalef's Richness index $\mathrm{R}$ & $\mathrm{R}_{1}=5.978$ \\
\hline Evenness Index & \\
\hline Pielou J Evenness Index & $\mathrm{J}=0.798$ \\
\hline
\end{tabular}

Table 4. Foraging guild of avian species detected in the Kot Dinghano Riverine forest habitat.

\begin{tabular}{lcc}
\hline \multicolumn{1}{c}{ Guild } & $\begin{array}{c}\text { Total No of } \\
\text { Individuals }\end{array}$ & $\begin{array}{c}\text { Percentage } \\
\text { (\%) }\end{array}$ \\
\hline Insectivore & 2740 & 27.60 \\
$\begin{array}{l}\text { Carnivore/Piscivore/ } \\
\text { Insectivore }\end{array}$ & 1882 & 18.95 \\
Granivore & 1571 & 15.82 \\
Frugivore/Insectivore & 1307 & 13.16 \\
Granivore/Insectivore & 1191 & 12.00 \\
Omnivore & 867 & 8.73 \\
Piscivore & 271 & 2.73 \\
Carnivore & 65 & 0.65 \\
Nectarivore/Insectivore & 21 & 0.21 \\
Carnivore/Insectivore & 14 & 0.14 \\
Total & $\mathbf{9 9 2 9}$ & \\
\hline
\end{tabular}

found that twiggy shrubs (35.88\%) and black honey shrubs (30.22\%) were the most common shrubs, accounting for approximately $65.0 \%$ of the total shrub proportion. In contrast, the apple of Sodom (3.67\%) and Bindii (1.14\%) were the rarest shrubs in the research area. Furthermore, according to IVI, camel thorn bush was the most common weed, accounting for $10.98 \%$ of the total, whereas bitter apple $(0.74 \%)$ was a rare weed that only covered a small portion of the research area. Similarly, giant cordgrass had the greatest index value, accounting for $33.16 \%$ of the ground cover, while Kapok Bush was the least prevalent, accounting for just $1.59 \%$ of the ground vegetation (Table 5 and Figure 6-9). Overall, the results of the IVI test demonstrated that riverine forests have a diverse range of floral species compositions and structures.

\section{Discussions}

Riverine forests are at the verge of preservation and protection due to the reliance of the population of local communities. These forests are experiencing elevated deforestation due to conversion to an agricultural field and human habitation (Fernandez-Juricic, 2004). The avian population structure has been seriously impacted by uncontrolled deforestation and degradation (Beier et al., 2002). Many forest-dependent bird species have been reported to be vulnerable or endangered as a result of habitat loss and degradation (Watson et al., 2004; Wright and Muller-Landau, 2006).

The presence of 57 bird species in the Kot Dinghano Riverine Forest demonstrated that it is a suitable habitat for a wide range of bird species to live and breed. This might be due to the abundance of food supplies in the riverine forest, such as grains, invertebrates (insects, worms), amphibians, reptiles, fishes, and small mammals, which met their needs (Rajpar and Zakaria, 2012). Furthermore, the findings revealed that bird species are habitat specialists with frequently tightly related plants. For example, $P$. neglectus, P. ochruros, and T. caudate were habitat specialists who frequently used the forest interior. Similarly, P. leucotis and $P$. cafer favored wetland habitats and forest margins dominated by shrubs ( $T$. tetanus and A. strepera).

The higher populations of the Eurasian collard doves (S. decaocto), white-eared bulbuls (P. leucotis), common babblers ( $T$. caudate) and gray francolin (F. pondicerianus) were recorded in riverine forest habitats. These bird species are less shy species with humans and plenty of food resources, i.e. diversity of grains, insects and fruits of shrubs that are major diet for these bird species. In addition, adjacent agriculture fields are also provided suitable habitats, rich in food grains and attractive to wide variety of insects. In contrast, lowest population was detected for lesser whitethroats (S. curruca), gray herons (A. cinerea) and Pallas fish eagle (H. leucoryphus). The reason was that, lesser whitethroat was migrant bird species; grey heron only utilized the waterlogged and wetland areas especially during flood season and Pallas fish eagle is vagrant in nature and always keep changes their location.

The results of foraging guilds revealed that foraging behavior varies greatly among bird species. Some species, such as fantails, flycatchers, and martins, were arboreal foragers (caught their prey on the wing by sallying in the air and tree canopy), whereas others were ambushed foragers (catch and kill their prey immediately; herons, egrets, and cormorant). Similarly, some bird species have been cryptic foragers, i.e., besra, eagles, and hawks, while others were solitary foragers, often hide in the bushes and shrubs to catch their prey; francolin, prinias, and warblers. However, some species were diving foragers, i.e., catch their prey while diving; grebes and cormorants, gregarious and social foragers (often concentrated where prey items occur in sufficient numbers; babblers, sparrows, bulbuls, and doves), and social dabbling foragers (often concentrated where prey items occur in sufficient numbers; babblers, sparrows, bulbuls, and doves), and social dabbling for (often forager on the surface of water in flocks on aquatic plants; ducks). Furthermore, several species were mud probers (probing in mud to obtain insects and invertebrates concealed in muck or soft soil; sandpipers, shanks, stilts, etc.) and nectar feeders, frequently nip the flower's nectar; sunbirds.

It was observed that the partridges, doves, babblers, and larks benefited from the ground vegetation, which was dominated by grasses and weeds. The partridges were 
Table 5. Vegetation structure and composition with importance value index.

\begin{tabular}{|c|c|c|c|}
\hline Family & Scientific Name & Common Name & $\begin{array}{c}\text { IVI } \\
\text { (Importance Value Index) }\end{array}$ \\
\hline \multicolumn{4}{|l|}{ Trees } \\
\hline Fabaceae & Acacia nilotica & Gum Arabic Tree & 23.91 \\
\hline Fabaceae & Prosopis cineraria & Jand & 17.64 \\
\hline Rhamnaceae & Ziziphus mauritiana & Indian Jujube & 14.85 \\
\hline Tamricaceae & Tamarix aphylla & Athel Tree & 14.98 \\
\hline Salicaceae & Populus euphratica & Bahan & 14.39 \\
\hline Minmosaceae & Acacia modesta & Phulai & 11.85 \\
\hline Salicaceae & Salix tertrasperma & Willow & 2.38 \\
\hline \multicolumn{4}{|l|}{ Shrubs } \\
\hline Tamricaceae & Tamarix dioica & Ghaz or Twiggy Shrub & 35.88 \\
\hline Phyllanthaceae & Phyllanthus reticulatus & Black Honey Shrub & 30.32 \\
\hline Poaceae & Saccharum spontaneum & Wild Sugar Cane & 14.95 \\
\hline Capparaceae & Capparis decidua & Karira & 13.04 \\
\hline Apocynaceae & Calotropis procera & Apple of Sodom & 3.67 \\
\hline Zygophyllaceae & Tribulus terrestris & Bindii & 1.14 \\
\hline \multicolumn{4}{|l|}{ Weed } \\
\hline Rhamnaceae & Alhaji maurorum & Camelthorn Bush & 11.98 \\
\hline Verbenaceae & Phyla nodiflora & Tangle Frogfruit & 10.96 \\
\hline Solanaceae & Solanum surattense & Yellow Fruit Nightshade & 9.83 \\
\hline Asteraceae & Launaea procumbens & Creeping Launaea & 6.32 \\
\hline Boraginaceae & Heliotropium $s p$ & Indian Helitrope & 6.26 \\
\hline Asteraceae & Sonchus asper & Spiny Swothistle & 6.25 \\
\hline Amaranthaceae & Chenopodium album & Pig Weed & 3.69 \\
\hline Polygonaceae & Polygonum plebeium & Knot Weed & 3.21 \\
\hline Phyllanthaceae & Phyllanthus sp & Black Catnip & 2.68 \\
\hline Euphorbiaceae & Euphorbia prostrata & Prostrate Sandmat & 1.69 \\
\hline Solanaceae & Solanum nigrum & Black Nightshade & 1.50 \\
\hline Asteraceae & Eclipta alba & False Daisy & 1.12 \\
\hline Cucurbitaceae & Citrullus colocynthis & Bitter Apple & 0.74 \\
\hline \multicolumn{4}{|l|}{ Grasses } \\
\hline Poaceae & Desmostachya bipinnata & Big Caordgrass & 33.16 \\
\hline Poaceae & Cynodon dactylon & Scutch Grass & 17.72 \\
\hline Amaranthaceae & Amaranthus viridis & Slender Amaranth & 5.73 \\
\hline Cypraceae & Cyperus sp & Nut Grass & 4.68 \\
\hline Amaranthaceae & Aerva javanica & Kapok Bush & 1.59 \\
\hline
\end{tabular}

found to be a sensitive and bashful species with a secretive demeanor. Anthropogenic activities such as habitat loss and degradation due to deforestation, unregulated grazing, and fuel wood collections easily disturb bird species. Seeds of herbaceous flora, acorns, legumes, and grains were foraged by doves and partridges. Bulbul also preferred to consume the fruits (berries) and insects found in grasses and bushes.
Moreover, Streptopelia decaocto and F. pondicerianus chose nearby agricultural fields in pursuit of food, refuge, and reproduction. The partridges were seen using scrub vegetation and brush-lined water channels for cover and grassy places for nesting. This might be because these isolated floral patches control heat, give shade, and provide protection from predators and harsh weather. The ecological significance of bird species, on the other 


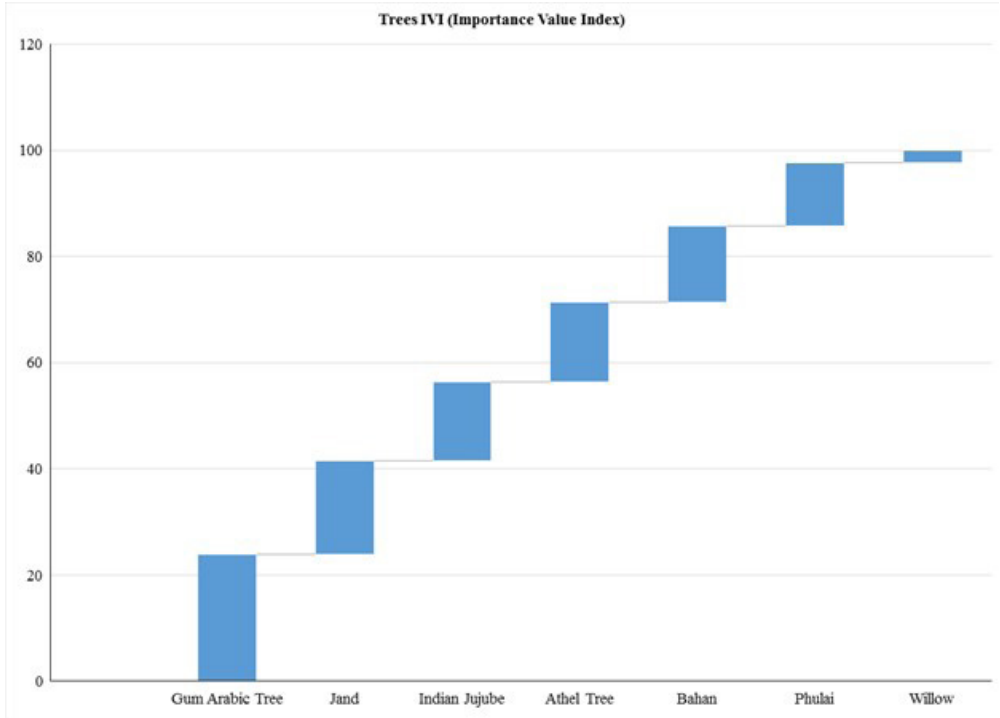

Figure 6. Importance value index of tree species of riverine forest habitat.

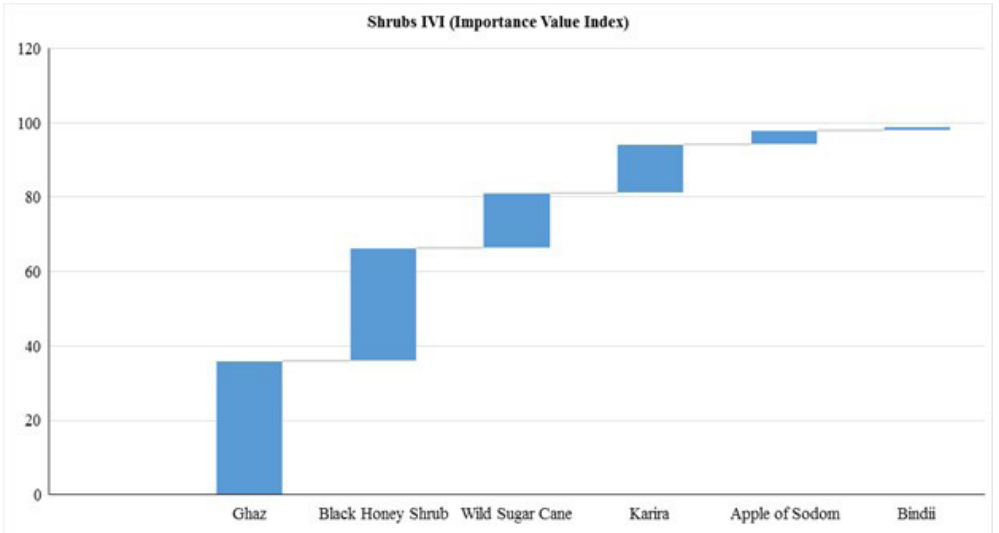

Figure 7. Importance value index of shrub species in riverine forest habitat.

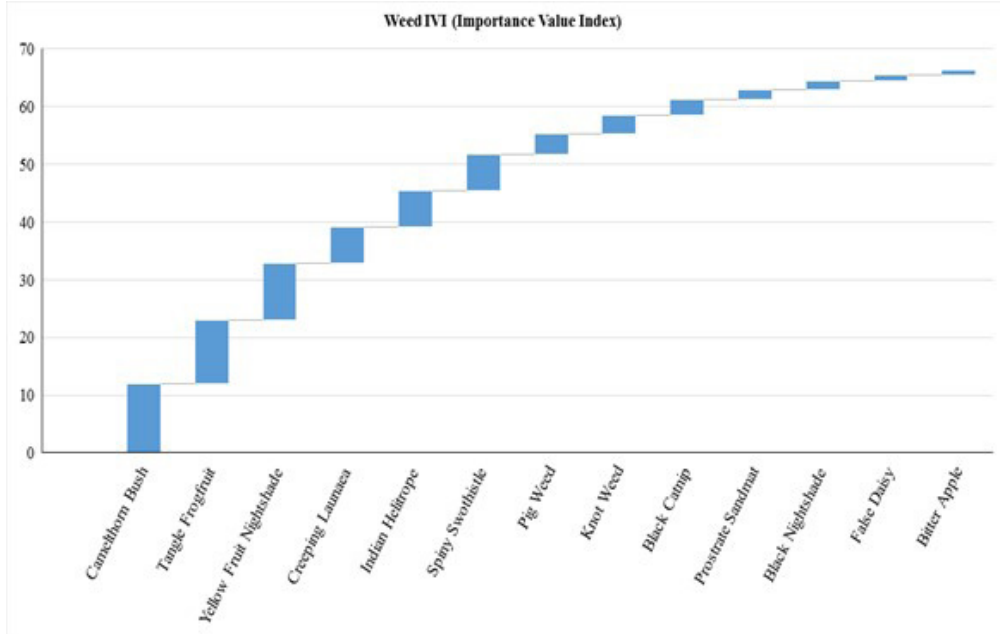

Figure 8. Importance value index of weed species of riverine forest habitat. 


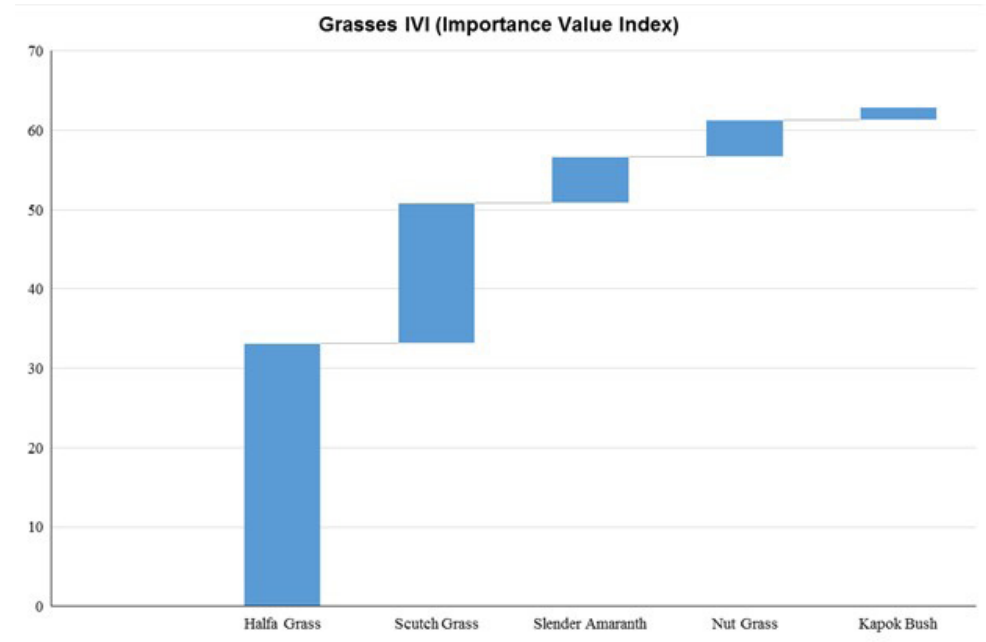

Figure 9. Importance value index of grass species of riverine forest habitat.

hand, may differ from species to species. Floral structures and compositions are major driving factors influencing habitat selection, food resource utilization, shelter, and breeding grounds for a variety of bird species. It has also been demonstrated that floral species composition, food availability, and climatic factors, such as temperature and relative humidity, impact bird relative abundance and dispersion (Mengesha and Bekele, 2008; McCain, 2009; Girma et al., 2017).

In all, 32 floral species were recorded from the riverine forest habitat, including trees (eight species), shrubs (six species), weeds (thirteen species), and grasses (five species). The IVI value revealed the riverine forest's ecological relevance, i.e., ecological advantages at several nested scales ranging from habitat to ecoregion and dominating floral species composition that suggest the capacity to maintain biodiversity. Furthermore, riverine forests may provide reliable data to help biodiversity protection and conservation methods.

Fuelwood collection and unrestricted grazing by livestock have put a strain on habitat production and breeding success of partridges, warblers, grass birds, and larks in the Kot Dinghano riverine forest, according to direct observation. Furthermore, encroachment, i.e., agricultural growth, places a strain on this riverine forest, which might result in habitat loss and degradation, significantly impacting the population of many bird species. Partridge populations in the Kot Dinghano Riverine forest have declined by more than $50 \%$, according to local communities, due to illegal hunting within adjacent agricultural habitats, heavy pesticide use, uncontrolled grazing by livestock, and human occurrence in breeding areas for the purposes of fuel wood, fodder, and honey collection, as well as incidence fire during honey collection.

\section{Conclusions}

Based on the results, it is concluded that the Kot Dinghano Riverine Forest is a highly productive and attractive habitat for a diverse range of bird species to meet their needs. Unfortunately, due to human meddling, this ecosystem is under a variety of threats and is rapidly deteriorating. As a result, it is strongly recommended that this crucially important riverine forest habitat be a conserved priority basis to improve the bird population.

\section{Acknowledgements}

The authors gratefully acknowledge the work from the United Nations Development Program (Sustainable Forest Management Unit, Sindh Pakistan). The authors would like to appreciate the Deputyship for Research and Innovation, Ministry of Education in Saudi Arabia, for funding this work through the Grant Number "375213500." The authors also extend their sincere appreciation to the central laboratory at Jouf University for the support of this study.".

\section{References}

BACHAN, K.H.A., 2003 [viewed 25 August 2013]. Riparian vegetation along the middle and lower zones of the Chalakkudy River, Kerala, India. Project Report 26/2000 [online]. Available from: https:// web.archive.org/web/20090319060415/http://krpcds.org/ report/amita.pdf

ANDERSON, A.S., MARQUES, T.A., SHOO, L.P. and WILLIAMS, S., 2015. Detectability in audio-visual surveys of tropical rainforest birds: the influence of species, weather and habitat characteristics. PLoS One, vol. 10, no. 6, pp. e0128464. http://dx.doi.org/10.1371/ journal.pone.0128464. PMid:26110433.

BARKER, P., 2001 [viewed 25 August 2013]. A technical manual for vegetation monitoring: resource management and conservation [online]. Hobart: Department of Primary Industries, Water and Environment, pp. 77. Available from: https://dpipwe.tas.gov. au/-Documents /Manual_screen.pdf

BEIER, P., VAN DRIELEN, M. and KANKAM, M.V., 2002. Avifaunal collapse in West African forest fragments. Conservation Biology, vol. 16, no. 4, pp. 1097-1111. http://dx.doi.org/10.1046/j.15231739.2002.01003.x. 
BIBBY, C.J.X., BURGESS, M.V., HILL, D.A. and MUSTOE, S.H., 2000. Bird Census Techniques. 2nd ed. London: Academic Press.

BLAKE, J.G. and LOISELLE, B.A., 2000. Diversity of birds along an elevational gradient in the Cordillera Central, Costa Rica. The Auk, vol. 117, no. 3, pp. 663-686. http://dx.doi.org/10.1093/ auk/117.3.663.

BUCKLAND, S.T., 2006. Point transects surveys for songbirds: robust methodologies. The Auk, vol. 123, no. 2, pp. 345-357. http://dx.doi.org/10.1093/auk/123.2.345.

BUCKLAND, S.T., ANDERSON, B.A., BURNHAN, K.P., LAKE, J.L., BORCHERS, D.L. and THOMAS, L., 2004. Advance distance sampling: estimating abundance of biological populations. London: Chapman \& Hall, pp. 141-172.

BURGER, J., 2006. Bioindicators: types, development, and use in ecological assessment and research. Environmental Bioindicators, vol. 1, no. 1, pp. 22-39. http://dx.doi. org/10.1080/15555270590966483.

CAHILL, A.J., WALKER, J.S. and MARSDEN, S.J., 2006. Recovery within a population of the Critically Endangered citron-crested cockatoo Cacatua sulphurea citrinocristata in Indonesia after 10 years of international trade control. Oryx, vol. 40, no. 2 , pp. 161-167. http://dx.doi.org/10.1017/S0030605306000366.

CAPON, S.J.,JAMES, C. and REID, M., eds. 2016. Vegetation of Australian riverine landscapes: biology, ecology and management. Australia: CSIRO Publishing Co., 407 p.

CARO, T., 2010. Conservation by Proxy: indicator, umbrella, keystone, flagship and other surrogate species. Washington: Island Press.

CLARKE, V., 2009 [viewed 25 August 2020]. Vegetation survey: establishing vegetation quadrats. SOP: 6.1 [online]. Kensington: DEC Nature Conservation Service. Available from: https:/| www.dpaw.wa. gov.au/images/ documents/plants-animals/ monitoring/ sop/sop_establishingvegetation quadrats_ 20090818_v1.0.pdf

CODESIDO, M. and BILENCA, D.N., 2000. Comparacion de los metodos de transecta de fajay de conteo de puntos de radio fijo en una comunidad de aves del bosque semiárido santiagueño. El Hornero, vol. 15, pp. 85-91.

DALE, S., MORK, K., SOLVANG, R. and PLUMPTRE, A.J., 2002. Edge effects on the understory bird community in a logged forest in Uganda. Conservation Biology, vol. 14, no. 1, pp. 265-276. http:// dx.doi.org/10.1046/j.1523-1739.2000.98340.x.

DESANTE, D.F., NOTT, M.P. and KASCHUBE, D.R., 2005. Monitoring, modelling, and management: why base avian monitoring on vital rates and how should it be done. In: C.J. RALPH and T.D. RICH, eds. Bird conservation implementation and integration in the Americas. Albany: U.S. Forest Service, pp. 795-804. (General Technical Report, no. PSW-GTR-191).

EHRLICH, P.R., DOBKIN, D.S. and WHEYE, D. 1988. The Birder's Handbook. A field guide to the natural history of American birds "The Essential Companion to your identification guide". New York: Touchstone, Simon and Schuster/Fireside Books, 816 p.

ELLISON, A.M., BANK, M.S., CLINTON, B.D., COLBURN, E.A., ELLIOTT, K., FORD, C.R., FOSTER, D.R., KLOEPPEL, B.D., KNOEPP, J.D., LOVETT, G.M., MOHAN, J., ORWIG, D.A., RODENHOUSE, N.L., SOBCZAK, W.V., STINSON, K.A., STONE, J.K., SWAN, C.M., THOMPSON, J., VON HOLLE, B. and WEBSTER, J.R., 2005. Loss of foundation species: consequences for the structure and dynamics of forested ecosystem. Frontiers in Ecology and the Environment. vol. 9, no. 9, pp. 479-486. http://dx.doi.org/10.1890/15409295(2005)003[0479:LOFSCF]2.0.CO;2.

FERNANDEZ-JURICIC, E., 2004. Spatial and temporal analysis of the distribution of forest specialists in an urban-fragmented landscape (Madrid, Spain): implications for the local and regional bird conservation. Landscape and Urban Planning, vol. 69, no. 1, pp. 17-32. http://dx.doi.org/10.1016/j.landurbplan.2003.09.001.

FREEMAN, S.N., POMEROY, D.E. and TUSHABE, H., 2003. On the use of timed species counts to estimate avian abundance indices in species-rich communities. African Journal of Ecology, vol. 41, no. 4, pp. 337-348. http://dx.doi.org/10.1111/j.13652028.2003.00481.x.

GRAAF, R.M., TILGHMAN, N.G. and ANDERSON, S.T., 1985. Foraging guilds of North American birds. Environmental Management, vol. 9, no. 6, pp. 493-536. http://dx.doi.org/10.1007/BF01867324.

GIRMA, Z., MAMO, Y., MENGESHA, G., VERMA, A. and ASFAW, T., 2017. Seasonal abundance and habitat use of bird species in and around Wondo Genet forest, South-central Ethiopia. Ecology and Evolution, vol. 7, no. 10, pp. 3397-3405. http:// dx.doi.org/10.1002/ece3.2926. PMid:28515875.

GLEN, S., 2021 [viewed 29 July 2021]. Simpson's diversity index: definition, formula, calculations [online]. Available from: https:// www.statisticshowto.com/simpsons-diversity-index/

GREGORY, R.D., GIBBONS, D.W. and DONALD, P.F., 2006. Bird census and survey techniques. In: W.J. SUTHERLAND, I. NEWTON and R.E. GREEN, eds. Bird ecology and conservation: a handbook of techniques Oxford: Oxford University Press, 386 p.

HENDERSON, P.A. and SEABY, R.M.H., 2007. Community analysis package 4.0. Lymington: Pisces Conservation Ltd.

HILL, M., EAMES, J.C., TRAI, L.T. and CU, N., 2001. Population sizes, status and habitat associations of forest birds in Chu Yang Sin Nature Reserve, Dak Lak Province, Vietnam. Bird Conservation International, vol. 11, no. 1, pp. 49-70. http://dx.doi.org/10.1017/ S095927090100106X.

INTERNATIONAL UNION FOR CONSERVATION OF NATURE AND NATURAL RESOURCES - IUCN, 2018 [viewed 1 April 2019]. IUCN red list [online]. Gland: IUCN. https://www.iucn.org/ theme/species/our-work/iucn-red-list-threatened-species

KAMINSKI, M.R., BALDASSARRE, G.A. and PEARSE, A.T., 2006. Waterbird responses to hydrological management of wetlands reserve program habitats in New York. Wildife Society Bulletin, vol. 34, no. 4, pp. 921-926. http://dx.doi.org/10.2193/00917648(2006)34[921:WRTHMO]2.0.CO;2.

KEIGHERY, B., 1994. Bushland plant survey: a guide for community surveys. Perth: Wildflower Society of Western Australia.

KHALIQUE, N., RAIS, M., MEHMOOD, T., ANWAR, M., ALI, S., BILAL, S. and KABEER, B., 2012. Study on some waterfowls of Mangla Dam, Azad Jammu and Kashmir. Berkut, vol. 21, pp. 44-49.

KHAN, B.N. and ALI, Z., 2015. Assessment of bird's fauna, occurrence status, diversity indices and ecological threats at Mangla Dam, AJK. Journal of Animals and Plant Sciences, vol. 25, no. 2, pp. 397-403.

LEE, D.C. and MARSDEN, S.J., 2008. Adjusting count period strategies to improve the accuracy of forest bird abundance estimates from point transect distance sampling surveys. The Ibis, vol. 150, no. 2 , pp.315-325. http://dx.doi.org/10.1111/j.1474-919X.2007.00790.x.

MARSDEN, S.J., 1999. Estimation of parrot and hornbill densities using a point count distance sampling method. The International Journal of Avian Science, vol. 141, no. 3, pp. 327-390. http:// dx.doi.org/10.1111/j.1474-919X.1999.tb04405.x.

MCCAIN, C.M., 2009. Global analysis of bird elevation diversity. Global Ecology and Biogeography, vol. 18, no. 3, pp. 346-360. http://dx.doi.org/10.1111/j.1466-8238.2008.00443.x.

MCGILL, B.J., ETIENNE, R.S., GRAY, J.S., ALONSO, D., ANDERSON, M.J., BENECHA, H.K., DORNELAS, M., ENQUIST, B.J., GREEN, J.L., HE, F., HURLBERT, A.H., MAGURRAN, A.E., MARQUET, P.A., MAURER, B.A., OSTLING, A., SOYKAN, C.U., UGLAND, K.I. and WHITE, 
E.P., 2007. Species abundance distributions: moving beyond single prediction theories to integration within an ecological framework. Ecology Letters, vol. 10, no. 10, pp. 995-1015. http:// dx.doi.org/10.1111/j.1461-0248.2007.01094.x. PMid:17845298.

MENGESHA, G. and BEKELE, A., 2008. Diversity and relative abundance of birds of Alatish National Park. International Journal of Ecology and Environmental Sciences, vol. 34, pp. 215-222. 8155920963200.

MERAWI, E., 2016. Identification of ecological threats, pressure and their relative severity of Temcha riverine forest, North West, Ethiopisa. American Journal of Agriculture and Forestry, vol. 4, no. 3, pp. 64-68. http://dx.doi.org/10.11648/j. ajaf.20160403.12.

MILLS, T.R., RUMBLE, M.A. and FLAKE, L.D., 2000. Habitats of birds in ponderosa pine and aspen/birch forest in the Black Hills, South Dakota. Journal of Field Ornithology, vol. 71, no. 2, pp. 187-206. http://dx.doi.org/10.1648/0273-8570-71.2.187.

MORRISON, M.L., 2009. Restoring wildlife: ecological concepts and practical applications. Washington: Island Press, 368 p. (The Science and Practice of Ecological Restoration Series).

NADEAU, C.P., CONWAY, C.J., SMITH, B.S. and LEWIS, T.E., 2008. Maximizing detection probability of wetland dependent bird during point count surveys in North-western Florida. The Wilson Journal of Ornithology, vol. 120, no. 3, pp. 513-518. http://dx.doi. org/10.1676/07-041.1.

RAJPAR, M.N. and ZAKARIA, M., 2012. Avian community parameters of freshwater wetland ecosystem in Peninsular Malaysia. Asia Life Sciences, vol. 21, pp. 1-19.

SCHIECK, J., 1997. Biased detection of bird vocalizations affects comparisons of bird abundance among forested habitats The Condor, vol. 99, no. 1, pp. 179-190. http://dx.doi. org/10.2307/1370236.

SCHULZ, B.K., BECHTOLD, W.A. and ZARNOCH, S.J., 2009. Sampling and estimation procedures for the vegetation diversity and structure indicator. Portland: US Department of Agriculture, Forest Service, Pacific Northwest Research Station, 53 p. (Gen. Tech. Rep., no. PNW-GTR-786).

SEKERCIOĞLU, C.H., DAILY, G.C. and EHRLICH, P.R., 2004. Ecosystem consequences of bird declines. Proceedings of the National Academy of Sciences of the United States of America, vol. 101, no. 52 , pp. 18042-18047. http://dx.doi.org/10.1073/pnas.0408049101. PMid:15601765.

STAVE, J., OBA, G., NORDAL, I. and STENSETH, N.C., 2007. Traditional ecological knowledge of a riverine forest in Turkana, Kenya: implications for research and management. Biodiversity and Conservation, vol. 16, no. 5, pp. 1471-1489. http://dx.doi. org/10.1007/s10531-006-9016-y.
SUTHERLAND, W.J., 2006. Ecological census techniques. a handbook. 2nd ed. Cambridge: Cambridge University Press. http://dx.doi. org/10.1017/CBO9780511790508.

THOMAS, L., BUCKLAND, S.T., REXSTAD, E.A., LAAKE, J.L., STRINDBERG, S., HEDLEY, S., BISHOP, J.R.B., MARQUES, T.A. and BURNHAM, K.P., 2010. Distance software: design and analysis of distance sampling surveys for estimating population size. Journal of Applied Ecology, vol. 47, no. 1, pp. 5-14. http://dx.doi. org/10.1111/j.1365-2664.2009.01737.x. PMid:20383262.

THOMPSON III, F.R., BURHANS, D.E. and ROOT, B., 2002. Effects of point count protocol on bird abundance and variability estimates and power to detect population trends. Journal of Field Ornithology, vol. 73, no. 2, pp. 141-150. http://dx.doi. org/10.1648/0273-8570-73.2.141.

THORNGATE, N., SCULLEN, J. and OSLON, J. 2006. Avian community dynamics in the lower Carmel river watershed 1992-2006-Annual Avian Monitoring Report. Salinas: Ventana Wildlife Society.

UMAR, M., HUSSAIN, M., MURTAZA, G., SHAHEEN, F.A. and ZAFAR, F., 2018. Ecological concerns of migratory birds in Pakistan: a review. Punjab University Journal of Zoology, vol. 33, no. 1, pp. 69-76. http://dx.doi.org/10.17582/pujz/2018.33.1.69.76.

VERBERK, W., 2011. Explaining general patterns in species abundance and distributions. Nature Education Knowledge, vol. 3, no. 10, pp. 38 .

VERNER, J. and PURCELL, K.L., 1999. Fluctuating populations of House Wrens and Bewick's Wrens in foothills of the western Sierra Nevada of California. The Condor, vol. 101, no. 2, pp. 219-229. http://dx.doi.org/10.2307/1369985.

VERNER, J. and RITTER, L.V., 1985. A comparison of transects and point counts in oak-pine woodlands of California. The Condor, vol. 87, no. 1, pp. 47-68. http://dx.doi.org/10.2307/1367130.

WARD, J.V., TOCKNER, K., ARSCOTT, D.B. and CLARET, C., 2002. Riverine landscape diversity. Freshwater Biology, vol. 47, no. 4, pp. 517-539. http://dx.doi.org/10.1046/j.1365-2427.2002.00893.x.

WATSON, J.E.M., WHITTAKER, R.J. and DAWSON, T.P., 2004. Habitat structure and proximity to forest edge effect the abundance and distribution of forest dependent birds in tropical coastal forest of southeastern Madagascar. Biological Conservation, vol. 120, no. 3, pp. 311-327. http://dx.doi.org/10.1016/j.biocon.2004.03.004.

WHITMAN, A.A., HAGAN III, J.M. and BROKAW, N.V.L., 1997. A comparison of two bird survey techniques used in a subtropical forest. The Condor, vol. 99, no. 4, pp. 955-965. http://dx.doi. org/10.2307/1370146.

WRIGHT, S.J. and MULLER-LANDAU, H.C., 2006. The future of tropical forest species. Biotropica, vol. 38, no. 3, pp. 287-301. http://dx.doi.org/10.1111/j.1744-7429.2006.00154.x. 